\title{
Uji Efektivitas Katalitik Herbal Rebusan Rimpang Lengkuas Sebagai Bahan Aktif Penghambat Bakteri Escherichia coli Terhadap Penyembuhan Diare Pada Balita
}

\author{
Robiatul Adawiyah*1 \\ ${ }^{1}$ Pendidikan kimia, FMIPA, Universitas Negeri Padang, Indonesia \\ *E-mail : robiatuladawiyah2901@gmail.com
}

\begin{abstract}
Abstrak. Telah dilakukan penelitian tentang pemanfaatan rebusan rimpang lengkuas sebagai obat tradisional terhadap penyembuhan diare yang berperan sebagai penghambat bakteri Escherichia coli. Metode yang dilakukan adalah eksprimen dan uji aktivitas katalik secara langsung. Tahapan pertama dilakukan dengan pembuatan ekstrak dari rimpang lengkuas, uji aktifitas dilakukan dengan variasi dua kali sehari. Hasil eksprimen membuktikan bahwa rebusan rimpang lengkuas dapat menyembuhkan diare dengan kondisi optimum rebusan rimpang lengkuas diminum sebanyak 6 sendok tecapai pada tiga hari. Penyembuahan ini diduga karena aktiftas katalik rebusan rimpang lengkuas terhadap penyembuhan diare.
\end{abstract}

\section{Key words: Obat tradisional, Rebusan Rimpang Lengkuas, Diare.}

\section{PENDAHULUAN}

Indonesia merupakan salah satu negara yang kaya akan sumber daya alamnya, hal ini membuat negara Indonesia dikenal sebagai salah satu negara penghasil sumber daya alam yang melimpah. Masyarakat Indonesia banyak memanfaatkan sumber daya

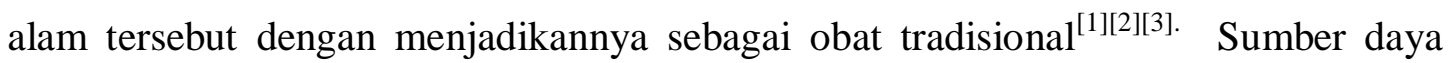
alam yang dimanfaatkan oleh masyarakat Indonesia sebagai obat tradisional sudah 
dilakukan sejak zaman nenek moyang ${ }^{[4][5][6]}$. Disamping sumber daya alam yang melimpah, pemanfaatan sumber daya alam sebagai obat tradisonal ini juga disebabkan karena memiliki efek samping yang bagus terhadap penyembuhan

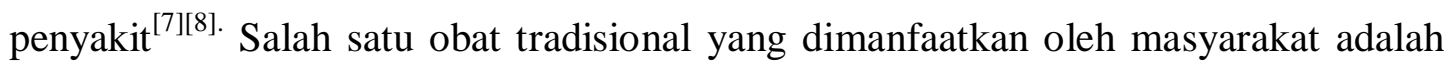
rimpang lengkuas sebagai obat diare (anti diare) ${ }^{[9][10]}$.

Diare merupakan salah satu penyakit yang dialami oleh manusia Karena adanya ketergangguan pencernaan didalam tubuh manusia ${ }^{[1] 12]}$. Salah satu penyebab diare ini akibat pola makan yang tidak bagus dan ketergantungan terhadap makanan yang tidak sehat ${ }^{[13][14][15]}$. Biasanya orang yang mengalami diare akan merasakan dehidrasi atau kekurangan cairan yang mengakibatkan penderita diare merasa lesu dan tidak memiliki semangat dalam menjalankan aktivitas sehari-hari ${ }^{[16][17][18]}{ }^{\text {. Dan }}$ hal ini sudah dibuktikan bahwa setiap penderita diare akan merasakan dehidrasi ataupun kekurangan cairan. Sehingga penyakit diare ini harus secepatnya ditangani agar penderita diare tidak mengalami dehidrasi atau kekurangan cairan ${ }^{[19][20][21]}$. Biasanya penyakit diare ini banyak diderita oleh anak-anak khususnya balita ( dibawah umur lima tahun) ${ }^{[22][23][24]}$. Hal ini disebabkan karena sistem kekebalan tubuh balita belum kuat sehingga rentan terhadap bakteri Escherichia coli yang menyebabkan balita menderita diare ${ }^{[25][26][27]}$.

Telah diketahui bahwa rimpang lengkuas ini bisa di jadikan sebagai obat diare (anti diare) bahkan sejak zaman nenek moyang obat tradisional ini sudah banyak digunakan oleh masyarakat umum. Karena ekstrak rimpang lengkuas bisa mengobati ataupun memiliki khasiat dalam mengobati diare ${ }^{[28][29][30]}$. Hal ini dikarenakan karena didalam rimpang lengkuas terdapat kandungan yang dapat mengahambat bakteri Escherichia coli, rimpang lengkuas ini berperan sebagai katalis dalam dalam penyembuhan diare pada anak balita ${ }^{[31][32][33]}$. Dimana katalis berperan untuk mempercepat reaksi penyembuhan diare. Selain berfungsi sebagai anti diare, di dalam rimpang lengkuas ini juga terdapat beberapa kandungan di dalamnya antara lain, minyak atsiri 1\%, senyawa eugenol, flavanoid dan lain sebaginya ${ }^{[34][35][36]}$. 
Dari beberepa kandungan senyawa yang terdapat dalam rimpang lengkuas ini juga memiliki manfaatnya masing-masing. Salah satunya adalah menetralkan keracunan makanan, meredakan rasa sakit, melancarkan buang air kecil, disentri, demam dan lain-lain ${ }^{[37][38][39]}$. Selain itu rimpang lengkuas ini juga dapat mengobati diabetes melitus, pada zaman nenek moyang orang menjadikan rimpang lengkuas sebagai obat ani diabetes ${ }^{[40][42][42]}$. Terdapat banyak komponen ataupun kandungan yang dapat dijadikan masyarakat sebagai obat tradisional ${ }^{[43][44][45]}$. Berdasarkan kandungan yang terdapat dalam rimpang lengkuas yaitu minyak atsiri $1 \%$ yang bisa dijadikan sebagai salah satu obat penyakit ${ }^{[46][47][48]}$. Namun karena kandungan minyak atsiri yang terkandung di dalam rimpang lengkuas hanya $1 \%$ hal ini menyebabkan masyrakat sejak zaman nenek moyang rimpang lengkuas dijadikan sebagai obat $\operatorname{diare}^{[49][49][50]}$.

Rebusan rimpang lengkuas merupakan salah satu obat herbal yang digunakan masyarakat salah satu obat anti diare ${ }^{[51][52][53]}$. Utamanya obat anti diare ini digunakan masyrakat pada balita ${ }^{[54][55][56]}$. Hal ini dikarenakan balita memiliki antibiotik yang kurang dan sistem imun yang tidak cukup untuk melawan bakteri yang menyerang tubuh anak. Rimpang lengkuas ini tidak hanya dimanfaatkan masyarakat sebagi rempah-rempah namun juga dijadikan sebagai obat tradisonal ${ }^{[57][58][59]}$. Hal ini didukung dengan berbagai penelitian yang menguatkan bahwa rebusan rimpang lengkuas dapat dijadikan sebagai obat tradisional ${ }^{[60][61][62]}$. Banyak para peneliti yang mendukung bahwa rebusan rimpang lengkuas dapat dijadikan sebagi obat tradisional ${ }^{[63][64][65]}$. Senyawa yang yang terdapat dalam rimpang lengkuas bisa menjadi penghambat berkembangnya bakteri Escheria coly dan dapat menigkatkan sistem imun pada anak balita ${ }^{[66][67][68]}$. Komponen-komponen yang terdapat dalam rimpang lengkuas saling berinteraksi dan saling bereaksi sehingga membentuk reaksi kimia $^{[69][70][71]}$.

Reaksi kimia merupakan suatu reaksi yang menghasilkan produk dengan melibatkan interaksi dua tau lebih pereaksi yang memiliki sifat kimia dan sifat fisika yang berbeda dengan pereaksinya ${ }^{[72][73][74]}$. Reaksi kimia terdiri dari reaksi spontan 
dan tidak spontan, dimana reaksi spontan adalah reaksi yang tidak membutuhkan energi melainkan namun membutuhkan katalis dalam reaksinya ${ }^{[75][76][77]}$. Sedangkan reaksi yang tidak spontan adalah suatu reaksi yang membutuhkan energy dalama melangsungkan reaksinya ${ }^{[78][79][80]}$.

Rimpang lengkuas merupakan salah satu katalitik herbal yang berperan sebagai penghambat bakteri Escherichia coli sehingga bisa dijadikan sebagai penyembuhan obat diare ${ }^{[81][82][83]}$. Dimana katalis herbal pada rimpang lengkuas ini merupakan suatu senyawa yang terkandung didalamnya yang berperan membantu laju reaksi sehingga dapat mempercepat taupun meyembuhkan penyakit diare $^{[84][85][86]}$. Didalam rimpang lengkuas ini terdapat komponen - komponen aktif yang dapat menyesak terjadinya laju reaksi dan didukung oleh komponen promotor untuk mengarahkan laju reaksi dari penyembuhan diare ${ }^{[87][88][89]}$. Selain itu didalam rimpang lengkuas ini juga terdapat komponen support yang berfungsi sebagai tempat penyedia $^{[90][91][92]}$. Tempat terjadinya laju reaksi sehingga rimpang lengkuas dapat dijadikan sebagai katalis herbal ${ }^{[33][94][95]}$. Katalis herbal merupakan salah satu obat tradisional paling ampuh dalam mengobati diare atau mempecepat reaksi penyembuhan diare ${ }^{[96][97][98]}$. Selain dijadikan sebagai obat diare didalam rebusan rimpang lengkuas terdapat kandungan yang dapat menyembuhkan demam yang berperan sebagai komponen aktif ${ }^{[99][100] 101]}$. Hal ini menandakan bahwa rimpang lengkuas merupakan salah satu obat tradisional yang sudah dijadikan masyarakat dari zaman nenek moyang ${ }^{[102][103][104]}$.

Pada saat sekarang rimpang lengkuas ini dijadikan masyarakat sebagai bumbu masakan saja, hal ini ditandai dengan ketidaktahuan masyarakat tentang hasiat dari rimpang lengkuas ${ }^{[105][106][107]}$. Hal ini dibuktikan dengan kecendrungan masyarakat mengonsumsi obat-obatan kimia yang beredar dipasaran ${ }^{[108][109][110]}$. Kandungan kimia yang terkandung didalam obat yang dikonsumsi oleh masyarakat sangat berbahaya bagi tubuh ${ }^{[111][112][113]}$. Hal ini ditandai efek samping yang dikeluhkan oleh masyarakat setelah mengonsumsi obat diare yang disebabkan oleh kandungan kimia pada obat diare ${ }^{[113][114][115]}$. Obat diare yang digunakan masyarakat bermacam-macam 
yaitu, untuk obat diare ringan masyarakat memberikan kepada penderita diare dengan mengonsumsi banyak cairan untuk mengantikan kehilangan cairan didalam tubuh $^{[116][117][118]}$. Berarti penderita diare diberikan minum yang lebih banyak atau minuman elektrolit, seperti minuman berenergi ${ }^{[19][120][121]}$. Untuk diare yang lebih serius, penderita diare biasanya dibawa kedokter untuk di infus ${ }^{[122][123][124]}$. Jika diare disebabkan oleh infeksi bakteri, dokter akan memberikan antibiotic ${ }^{[125][126][127] .}$ Dokter atau apoteker dapat memberikan cairan dehidrasi oral (sejenis peggani cairan untuk mencegah atau mengatasi dehidrasi, utamanya yang disebakan oleh bakteri) ${ }^{[128][129][130]}$. Cairan dehidrasi dapat memberikan tubuh glukosa, garam, dan mineral penting lainnya yang hilang selama dehidrasi ${ }^{[131][132][133]}$. Cairan dehidrasi oral cocok diberikan untuk diare pada anak -anak dan orang tua, dan dijual diapotik tapa resep ${ }^{[134][135][136]}$.

untuk menghindari efeksamping tersebut masyarakat juga bisa memberikan obat rumahan atau obat tradisional dalam penyembuhan diare pada balita ${ }^{[137][138][139]}$. Gaya hidup dan pengobatan rumahan dapat membantu mengatasi diare pada belita adalah memberikan jus buah tanpa gula tambahan ada anak, mengokonsumsi makanan kaya akan pottaium, seperti pisang, kentang daan lain ${ }^{[140][141][142]}$. Dan obat tradisional yang paling ampuh dalam pengobatan diare adalah memberikan rebusan rimpang lengkuas pada balita ${ }^{[143][144][145][146]}$. Dan hal ini sudah diteliti bahwa rebusan rimpang lengkuas aman untuk dikonsumsi oleh balita sehingga seorang ibu tidak perlu khawatir ${ }^{[147][148][149][150]}$.

\section{Metode Pelaksanaan}

Metode pelaksaan ini dilakukan dengan eksprimen secara langsung yang terdiri atas tiga hal yaiu sebagai berikut:

1. Peralatan yang dipakai

Peralatan yang dipaki adalah Gelas Kig Indonesia 200 mL 1 buah, Kompor Hock 1 buah, Pisau Cutter 1 buah, Saringan Horse Star 1 buah, Sendok stanless stell 1 buah, Panci Stanless dan Korek api Tokai

2. Bahan Yang Digunakan 
Bahan yang digunakan Air Aqua $400 \mathrm{~mL}$ dan rimpang lengkuas 10 gram yang dibeli pasar.

3. Prosedur Kerja

a. Persiapan sampel

Sampel diambil dari lokasi pertanian di daerah dataran rendah tepatnya di jalan Parkit 1, Air Tawar Barat Padang, Padang Utara, Sumatera Barat.

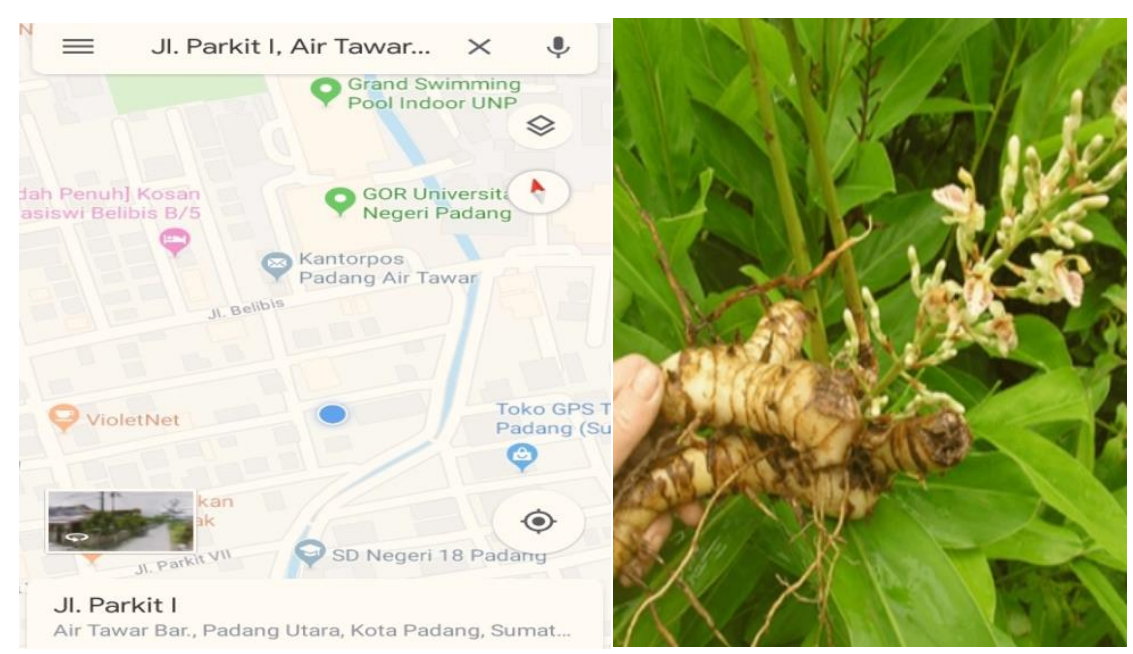

\section{Gambar 1: Lokasi Pengambilan Rimpang Lengkuas Dan Rimpang Lengkuas}

b. Pembuatan rebusan rimpang lengkuas

Rebusan rimpang lengkuas dibuat dengan cara merebus rimpang lengkuas dengan air. hal ini dilakukan dengan metode secara langsung yaitu dengan merebus rimpang lengkuas sebanyak 10 gram di dalam $400 \mathrm{~mL}$ atau 2 gelas air. Setelah itu dipanaskan sampai mendidih. Mendingankan rebusan rimpang lengkuas salam beberapa menit, setelah rebusan rimpang lengkuas dingin disaring dengan penyaring dan dipindakan kedalam wadah yang lain. Dan dipatkan hasil rebusan rimpang lengkuas untuk diberikan kepada penderita diare. 


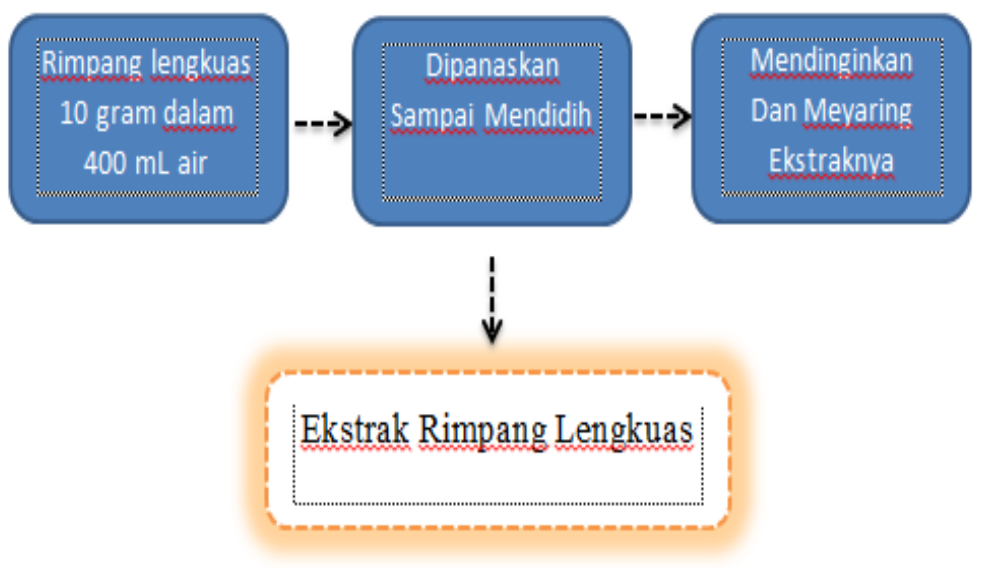

\section{Gambar 2 : Diagram Alir Pembuatan Ekstrak Rimpang Lengkuas}

\section{Hasil}

\section{Hasil Pembuatan Rebusan Rimpang Lengkuas}

Berdasarkan uji coba yang telah dilakukan didapatkan rebusan rimpang lengkuas sebanyak 10 gram dalam $400 \mathrm{~mL}$ air didapati rebusan rimpang lengkuas sebanyak $200 \mathrm{~mL}$. Hal ni dapat dimuat pada gambar berikut:

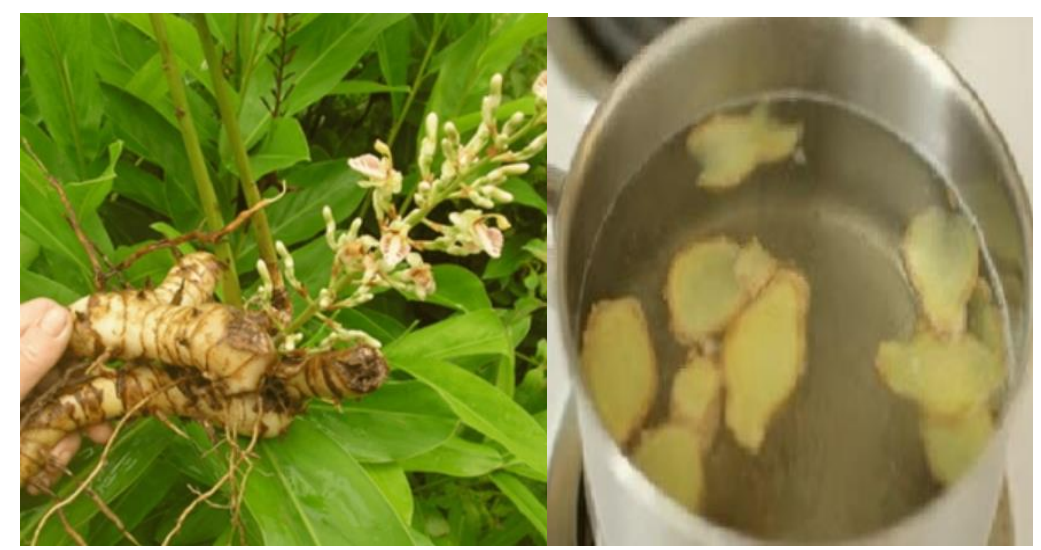

(a)

(b) 


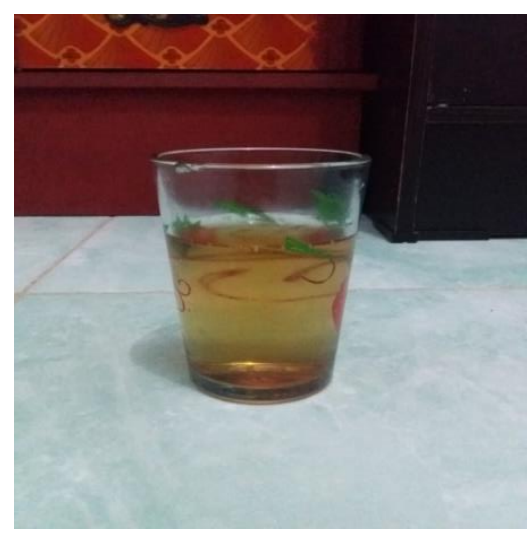

(c)

\section{Gambar 3 : Gambar 3 : https://images.app.goo.gl/S6ky1kfH8iZe6pJ98 (a) https://images.app.goo.gl/Ut6BBzbHdd6bPbEh7 (b) Rebusan Rimpang Lengkuas(c)}

\section{Hasil Uji Coba}

Berdasarkan pengujian dilakukan terhadap penderita penyakit diare ternyata berhasil menyembuhkan diare. Dimana rebusan rimpang lengkuas ini setelah dikonsumsi oleh penderita diare dapat memulihkannya. Hal ini ditandai dengan saat penderita diare (balita) mengonsumsi dua sendok sebanyak 2 kali dalam sehari. Ternyata secara optimum setelah dikonsumsi selama 4 hari telah memberikan hasil bahwa diare yang dialami oleh penderita dapat disembuhkan oleh rebusan rimpang lengkuas. Hal ini membuat masyarakat semakin percaya akan khasiat dari rebusan rimpang lengkuas tersebut terhadap penyembuhan diare.

Selain memberikan uji hasil postitif bagi masyarakat rebusan rimpang lengkuas ini juga dapat mengindari diare. Berikut adalah hasil positif dari rimpang lengkuas yang dapat menyembuhkan diare: 


\begin{tabular}{|c|c|c|}
\hline Hari & Hasil & Persentase Hasil \\
\hline 1 & + & $20 \%$ \\
\hline 2 & + & $60 \%$ \\
\hline 3 & + & $80 \%$ \\
\hline 4 & + & $100 \%$ \\
\hline
\end{tabular}

\section{Tabel 1 : Hasil Positif Uji Efektivitas Katalik Herbal Terhadap Penyembuhan Penyakit Diare}

\section{Pembahasan}

Berdasarkan penelitian yang dilakukan terhadap efektifitas katalitik herbal rebusan rimpang lengkuas terdapat komponen aktif yang dapat menghambat bakteri Escherichia coli yang berkembang didalam tubuh manusia. Dimana bakteri Escherichia coli merupakan salah satu faktor yang menyebabkan penyakit diare pada manusia. pada percobaan yang dilakukan dimana uji efektivitas dilakukan pada rimpang lengkuas sebanyak 10 gram didalam $400 \mathrm{ml}$ air yang menghasilkan $200 \mathrm{ml}$ rebusan rimpang lengkuas. Rebusan rimpang lengkuas ini dilakukan dengan metode perebusan terhadap rimpang lengkuas selama beberapa menit / sampai mendidih. Setelah rebusan rimpang lengkuas tersebut mendidih kemudian didinginkan selama beberapa menit sampai ekstrak rimpang lengkuas tersebut bisa dikonsumsi oleh anakanak. Setelah itu rebusan yang masih ada didalam panci disaring dan dipindahkan ke gelas berukururan $200 \mathrm{ml}$.

Berdasarkan uji hasil positif yang dilakukan secara optimum rebusan rimpang lengkuas dikonsomsi selama 4 hari . Rebusan rimpang lengkuas yang dibuat untuk anak - anak biasanya ditambahkan sedikit gula hal ini disebabkan agar nafsu makan dari anak balita tidak menurun. Rebusan rimpang lengkuas ini merupakan salah satu obat tradisonal yang dijadikan masyarakat secara turun temurun bahkan sejak zaman nenek moyang obat ini sudah digunakan oleh masyarakat umum. Hal ini disebabkan 
karena adanya komponen aktif dalam rimpang lengkuas tersebut. Kandungan senyawa yang terdapat dalam rimpang lengkuas terdiri dari minyak atsiri, eugenol seskuiterpen, pinen, metil sinamat, kaemferida, galagang dan Kristal kuning. Berdasarkan kandungan senyawa yang terdapat dalam rimpang lengkuas tersebut terdapat beberapa komponen aktif yang dapat membunuh atau menghentiakan bakteri Escherichia coli berkembang biak didalam tubuh manusia.

Biasanya balita merupakan salah satu predator ataupun mangsa yang diserang oleh bakteri Escherichia coli sebab tubuhnya rentan terhadap masuknya bakteri kedalam tubuhnya . hal ini disebabkan kekebalan tubuh pada balita masih sangat minim sehingga mempermudah bakteri berkembang biak didalam tubuh balita. Balita yang mengalami diare mengakibatkan akan dehidrasi atau kekurangan cairan sehingga balita yang menderita penyakit diare akan merasa lesu dan kurang beraktivitas pada kegiatan sehari - harinya. Salah satu komponen aktif yang terdapat pada rimpang lengkuas yang berfungsi menghambat atau mematikan bakteri Escherichia coli adalah minyak atsiri yang terkandung didalam nya. Dimana minyak atsiri tersebut akan menyerang dinding sel atau membaran sel dari bakteri dimana hal ini tegangan permukaan turun karena membaran sel rentan terhadap zat kimia yang menyerangnya sehinnga dapat mematikan bakteri Escherichia coli didalam tubuh.

Rebusan rimpang lengkuas yang dibuat ternyata memberikan gurva naik secara signifikan hal dapat ditandai dengan hasil positif yang terdapat pada table 1. Dimana setiapa haeri mengonsumsi ekstrak rimpang lengkuas tersebut ternya terdapat perubahan yang baik sehinga dapat dinyatakan bahwa rebusan rimpang lengkuas ini baik diguakan sebagai obat penyembuh diare dengan menghentikan bakteri Escherichia coli di dalam tubuh balita. 


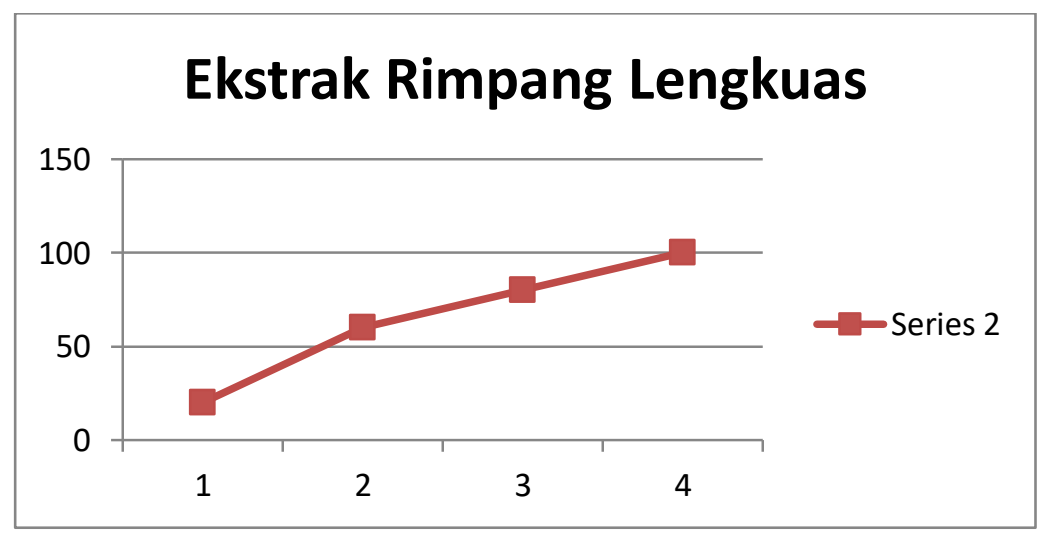

Kurva 1. Uji kenaikan terhadap efektivitas rimpang lengkuas sebagai obat diare

\section{Kesimpulan}

1. Rebusan yang dibuat dari rimpang lengkuas sebanyak 10 gram dalam $400 \mathrm{ml}$ didapatkan ekstrak sebanyak $200 \mathrm{ml}$.

2. Rebusan ini dapat menyembuhkan diare karna adanya komponen aktif didalam rimpang lengkuas yaitu minyak atsiri yang beran aktif menghambat berkembangnya bakteri Escherichia coli.

3. Rebusan rimpang lengkuas yang bekerja secara optimum setelah dikonsumsi empat hari.

\section{Referensi}

[1]. Lumbessy, Mirna, Abidjulu, Jemmy, Paendong, Jessy J. E. 2013. Uji Total Flavonoid Pada Beberapa Tanaman Obat Tradisonal Di Desa Waitina Kecamatan Mangoli Timur Kabupaten Kepulauan Sula Provinsi Maluku Utara. Jurnal Mipa Unsrat Online. Vol 2, No 1.

[2]. Katili, Abubakar Sidik . 2009. Kebijakan Pemanfaatan Dan Pengawasan Dalam Pengelolaan Sumber Daya Alam. Jurnal Legalitas. Vol 2, No 1. 
[3]. Setyoningsih, Ayu, Artaria, Myrtati D. 2016. Pemilihan Penyembuhan Penyakit Melalui Pengobatan Tradisional Non Medis Atau Medis. Jurnal Masyarakat, Kebudayaan Dan Politik. Vol 29, No 1.

[4].Oka Adi Parwata, I M., Sastra Dewi, P. Fanny . 2008. Isolasi Dan Uji Aktivitas Antibakteri Minyak Atsiri Dari Rimpang Lengkuas (Alpinia Galanga L.). Journal Of Chemistry. Vol. 2, No. 2.

[5]. Nuraida, Lilis, Hana, ., Hartanti, Apriliana W., Prangdimurti, Endang . 2012. Potensi Lactobacillus Yang Diisolasi Dari Air Susu Ibu Untuk Mencegah Diare [Potential Of Lactobacillus Isolated From Breast Milk To Prevent Diarrheae]. Jurnal Teknologi Dan Industri Pangan. Vol 23, No 2.

[6]. Harlis, Harlis. 2010. Uji Aktivitas Anti Bakteri Ekstrak Patikan Kerbau (Euphorbia Hirta L.) Terhadap Pertumbuhan Bakteri Penyebab Diare (Eschercia Coli). Jurnal Biospecies. Vol 3, No 2.

[7]. Anwar, Yunika, Maas, Linda, Bakti, Alam . 2013. Gambaran Perilaku Ibu Tentang Penanganan Awal Diare Dalam Mencegah Terjadinya Dehidrasi Pada Balita Di Kelurahan Tegal Sari Mandala Iii Kecamatan Medan Denai Tahun 2012. Jurnal Kebijakan, Promosi Kesehatan Dan Biostatiskik. Vol 2, No 1.

[8]. Delfican, Delfican, Jurnalis, Yusri Dianne, Bachtiar, Hafni, Putra, Andani Eka . 2014. Faktor Yang Berhubungan Dengan Terjadinya Infeksi Clostridium Difficile Pada Penderita Diare Akibat Antibiotik. Jurnal Sari Pediatri. Vol 15, No 6.

[9]. Wahyudin, Uyu, Besral . 2006. Penggunaan Obat Yang Tidak Rasional Pada Balita Dengan Diare Di Kalangan Bidan, Di Kabupaten Sumedang Tahun 2006. Jurnal Kesmas The National Journal Of Public Health. Vol. 1 No. 3.

[10]. Saprian, Saprian, Juliany, Any, Nurmiyanto, Awaluddin . 2014. Uji Efektivitas Jeruk Nipis (Citrus Aurantifolia) Dalam Mempercepat Laju Disinfeksi Bakteri Escheria Coli Pada Proses Solar Water Disinfection. Jurnal Sains Dan Teknologi Lingkungan. Vol 6, No 1.

[11]. Hanum, Tirza. 2000. Ekstraksi Dan Stabilitas Zat Pewarna Alam Dari Katul Beras Ketan Hitam (Oryza Sativa Glutinosa)*) Extraction And Stability Of Natural 
Colorant From Red Glutinous Rice Bran (Oryza Sativa Glutinosa). Jurnal Teknologi Dan Industri Pangan. Vol 11, No 1

[12]. Estiasih, Teti, Ahmadi, Kgs ., Nisa, Fithri Choirun, Khuluq, Ahmad Diaul. 2010. Ekstraksi Dan Fraksinasi Fosfolipid Dari Limbah Pengolahan Minyak Sawit [Extraction And Fractionation Of Phospholipids From The Waste Of Palm Oil Processing]. Jurnal Teknologi Dan Industri Pangan. Vol 21, No 2

[13]. Hong, Ng Tze, Ibrahim, Nor Hayati. 2012. Extraction And Characterization Of Mucilage From Leaves Of Pereskia Bleo (Rose Cactus) [Ekstraksi Dan Karakterisasi Dari Getah Daun Kaktus Mawar (Pereskia Bleo)]. Jurnal Teknologi Dan Industri Pangan. Vol 23, No 2

[14]. Tin, Farah Fahma Dept. 2006. Permodelan Matematika Ekstraksi Oleoresin Temulawak (Curcuma Xanthorrizha Roxb) Dengan Karbondioksida Superkritis Dan Co-Solvent Etanol Menggunakan Shrinking Core Model. Jurnal Teknologi Industri Pertanian. Vol 16, No 3

[15]. Argo, Bambang Dwi. 2010. Analisis Sistem Proses Pindah Massa Pada Ekstraksi Secara Mekanik Minyak Kedelai (Glycine Max Oil). Jurnal Keteknikan Pertanian. Vol 24, No 2.

[16]. Sinurat, Ellya, Kusumawati, Rinta. 2017. Optimasi Metode Ekstraksi Fukoidan Kasar Dari Rumput Laut Cokelat Sargassum Binderi Sonder -Optimization Of Crude Fucoidan Extraction Methods From Brown Seaweed Sargassum Binderi Sonder. Jurnal Pascapanen Dan Bioteknologi Kelautan Dan Perikanan. Vol 12, No 2

[17]. Winarni, Ade. 2012. Ekstraksi Ciri Citra Batik Menggunakan Co-Occurrence Matrix, Color Moment Dan K-Nearst Neighbor. Jurnal Lontar Komputer. Vol 3, No 2.

[18]. Mardina, Primata, Astarina, Eka N., Aquarista, Septriani. 2011. Pengaruh Kecepatan Putar Pengaduk Dan Waktu Operasi Pada Ekstraksi Tannin Dari Mahkota Dewa. Journal Of Chemistry. Vol. 5, No. 2.

[19]. Suarsa, I Wayan, Suarya, Putu, Kurniawati, Ika. 2011. Optimasi Jenis Pelarut Dalam Ekstraksi Zat Warna Alam Dari Batang Pisang Kepok (Musa Paradiasiaca L. Cv Kepok) Dan Batang Pisang Susu (Musa Paradiasiaca L. Cv Susu). Journal Of Chemistry. Vol. 5, No. 1 
[20]. Miwada, In. Sumerta, Simpen, In. 2007. Optimalisasi Potensi Ceker Ayam (Shank) Hasil Limbah Rpa Melalui Metode Ekstraksi Termodifikasi Untuk Menghasilkan Gelatin. Jurnal Ilmiah Peternakan. Vol 10, No 1.

[21]. Suartha, I Nyoman, Teguh Wibawan, I Wayan, Shinta Mayasari, Ratu. 2006. Perbandingan Antara Metode Peg-Amonium Sulfat Dan Peg-Kloroform Untuk Ekstraksi Dan Purifikasi Igy Kuning Telur. Jurnal Veteriner. Vol 7, No 4.

[22]. Katja, Dewa G. 2012. Kualitas Minyak Bunga Matahari Komersial Dan Minyak Hasil Ekstraksi Biji Bunga Matahari (Helianthus Annuus L.). Jurnal Ilmiah Sains. Vol 12, No 1.

[23]. Albert, Sani M. Isa. 2004. Perbandingan Tingkat Akurasi Metode Ekstraksi Fitur Antara Dct Dan Fft Untuk Pengenalan Wajah Menggunakan Algoritma Mbpnn. Komputer Dan Informatika. Vol. 5, No 2

[24]. Irene Juliani, Sani Muhamad Isa. 2005. Perbandingan Tingkat Akurasi Metode Ekstraksi Fitur Antara Dct Dan Eigenfaces Menggunakan Algoritma Euclidean Distance Pada Sistem Pengenalan Wajah. Jurnal Komputer Dan Informatika. Volume 6 No.1

[25]. Jos, Bakti, Pramudono, Bambang, Aprianto, Aprianto. 2011. Ekstraksi Oleoresin Dari Kayu Manis Berbantu Ultrasonik Dengan Menggunakan Pelarut Alkohol. Jurnal Reaktor. Volume 13, Nomor 4

[26]. Helmi, Muhammad, Hartoko, Agus, S, Herkiki, Munasik, Munasik, Wouthuyzen, S. 2011. Analisis Respon Spektral Dan Ekstraksi Nilai Spektral Terumbu Karang Pada Citra Digital Multispektral Satelit Alos-Avnir Di Perairan Gugus Pulau Pari, Kepulauan Seribu, Jakarta. Buletin Oseanografi Marina. Vol 1, No 1.

[27]. Jos, Bakti, Eko Setyawan, Prayudi, Satria, Yudha. 2011. Optimalisasi Ekstraksi Dan Uji Stabilitas Phycocyanin Dari Mikroalga Spirulina Platensis. Jurnal Tekhnik. Volume 32, Nomor 3.

[28]. Setia Budi, Faleh. 2009. Pengambilan Oleoresin Dari Ampas Jahe (Hasil Samping Penyulingan Minyak Jahe) Dengan Proses Ekstraksi. Jurnal Tekhnik. Volume 30, Nomor 3. 
[29]. Iswendi, Iswendi. 2009. Penentuan Aktivitas Amilase Dari Umbi Bengkuang (Pachyrrizus Arosus L.Urb) Hasil Ekstraksi Etanol Dan Ammonium Sulfat. Sainstek. Vol 12, No 1

[30]. Suharjo \& Noor Harini. 2005. Ekstraksi Chitosan Dari Cangkang Udang Windu (Penaeus Monoodon Sp.) Secara Fisik Kimia (Kajian Berdasarkan Ukuran Partikel Tepung Chitian Dan Konsentrasi Naoh). Jurnal Gamma. Vol 1, No 1.

[31]. Sinaga, E., \& Noverita, F. D. (2009). Daya Antibakteri Jamur Endofit Yang Diisolasi Dari Daun Dan Rimpang Lengkuas (Alpinia Galanga Sw.). Jurnal Farmasi Indonesia, 4(4), 161-164.

[32]. Wathoni, N., Rusdiana, T., \& Hutagaol, R. Y. (2009). Formulasi Gel Antioksidan Ekstrak Rimpang Lengkuas (Alpinia Galanga L. Willd) Dengan Menggunakan Basis Aqupec 505 Hv. Farmaka, 7(1), 15-27.

[33]. Hernani, T. M., \& Winarti, C. (2007). Pemilihan Pelarut Pada Pemurnian Ekstrak Lengkuas (Alpinia Galanga) Secara Ekstraksi. J. Pascapanen, 4(1), 1-8.

[34]. Sumayani, K. R., \& Cahyoko, Y. (2008). Daya Antibakteri Perasan Rimpang Lengkuas (Alpinia Galanga) Dengan Konsentrasi Berbeda Terhadap Pertumbuhan Aeromonas Hydrophila Secara In Vitro. Berkala Ilmiah Perikanan, 3(1), 83-87.

[35]. Florensia, S., Dewi, P., \& Utami, N. R. (2012). Pengaruh Ekstrak Lengkuas Pada Perendaman Ikan Bandeng Terhadap Jumlah Bakteri Pengaruh Ekstrak Lengkuas Pada Perendaman Ikan Bandeng Terhadap Jumlah Bakteri. Life Science, l(2).

[36]. Kusriani, R. H., \& Zahra, S. A. (2015). Skrining Fitokimia Dan Penetapan Kadar Senyawa Fenolik Total Ekstrak Rimpang Lengkuas Merah Dan Rimpang Lengkuas Putih (Alpinia Galanga L.). Prosiding Snapp: Kesehatan (Kedokteran, Kebidanan, Keperawatan, Farmasi, Psikologi), 1(1), 295-302.

[37]. Salni, S., Aminasih, N., \& Sriviona, R. (2013). Isolasi Senyawa Antijamur Dari Rimpang Lengkuas Putih (Alpinia Galanga (L.) Willd) Dan Penentuan Konsentrasi Hambat Minimum Terhadap Candida Albicans. Prosiding Semirata 2013, 1(1).

[38]. Sari, L. O. R. K. (2012). Pemanfaatan Obat Tradisional Dengan Pertimbangan Manfaat Dan Keamanannya. Pharmaceutical Sciences And Research (Psr), 3(1), 1-7.

[39]. Pribadi, E. R. (2015). Pasokan Dan Permintaan Tanaman Obat Indonesia Serta Arah Penelitian Dan Pengembangannya. Perspektif, 8(1), 52-64. 
[40]. Setyowati, H., Hanifah, H. Z., \& Nugraheni, R. P. (2013). Krim Kulit Buah Durian (Durio Zibethinus L.) Sebagai Obat Herbal Pengobatan Infeksi Jamur Candida Albicans. Program Kreativitas Mahasiswa-Penelitian.

[41]. Trisunaryanti, W., Triwahyuni, E., \& Sudiono, S. (2005). Preparasi, Modifikasi Dan Karakterisasi Katalis Ni-Mo/Zeolit Alam Dan Mo-Ni/Zeolit Alam. Jurnal Fakultas Hukum Uii, 10(4).

[42]. Ulfah, E. M., Yasnur, F. A., \& Istadi, I. (2006). Optimasi Pembuatan Katalis Zeolit X Dari Tawas, Naoh Dan Water Glass Dengan Response Surface Methodology. Bulletin Of Chemical Reaction Engineering \& Catalysis, 1(3), 26-32.

[43]. Brahim, T. K. (2007). Peningkatan Hasil Belajar Sains Siswa Kelas Iv Sekolah Dasar, Melalui Pendekatan Pemanfaatan Sumber Daya Alam Hayati Di Lingkungan Sekitar. Jurnal Pendidikan Penabur, 9(6), 37-49.

[44]. Royandi, E., Satria, A., \& Saharuddin, S. (2019). Kelompok Kepentingan Dan Relasi Kuasa Dalam Pengelolaan Sumber Daya Laut Palabuhanratu. Jurnal Kebijakan Sosial Ekonomi Kelautan Dan Perikanan, 8(2), 163-173.

[45]. Sulisyati, R., Prihatinningsih, P., \& Mulyadi, M. (2019, February). Revisi Zonasi Taman Nasional Karimunjawa Sebagai Upaya Kompromi Pengelolaan Sumber Daya Alam. In Seminar Nasional Geomatika (Vol. 3, Pp. 713-724).

[46]. Diningrat, D. S., Budiarta, K., \& Mulyana, D. (2018). Sinergitas Pengelolaan Sumber Daya Alam, Lingkungan Dan Kesejahteraan Masyarakat Kota Medan. Jurnal Pembangunan Perkotaan, 6(2), 117-126.

[47]. Hermawan, H., \& Ghani, Y. A. (2018). Geowisata: Solusi Pemanfaatan Kekayaan Geologi Yang Berwawasan Lingkungan. Jurnal Sains Terapan Pariwisata, 3(3), 391-408.

[48]. Brucles, L. D., Kurniawan, R., \& Adrianto, S. (2019). Aplikasi Panduan Praktis Obat Herbal Untuk Penyakit Dalam Berbasis Platform Android. Informatika, 10(2), 40-46.

[49]. Kurniawati, F. R. (2019). Hubungan Penggunaan Obat Herbal (Jamu Gepyok) Dengan Produksi Asi Di Bps Ds. Ngumpakdalem Kec. Dander Kabupaten Bojonegoro Tahun 2017. Journal Of Health Sciences, 12(1), 55-59.

[50]. Heryanto, R. M., Setiawan, Y. T., \& Arisandhy, V. (2019). Pengendalian Persediaan Produk Obat Herbal Pada Permintaan Probabilistik Menggunakan Joint Economic Lot Size. Jurnal Rekayasa Sistem Industri, 8(1), 39-46. 
[51]. Fauzi, F., Widodo, H., \& Haryanti, S. (2019). Kajian Tumbuhan Obat Yang Banyak Digunakan Untuk Aprodisiaka Oleh Beberapa Etnis Indonesia. Media Penelitian Dan Pengembangan Kesehatan, 29(1), 51-64.

[52]. Zubir, Z. (2019). Dukun Patah Tulang Dan Obatan Tradisional Di Nagari Koto Anau, Kabupaten Solok Propinsi Sumatera Barat Tahun 1960-2012. Historia Jurnal Program Studi Pendidikan Sejarah, 7(1), 61-78.

[53]. Kurniati, C. H., \& Azizah, A. N. (2019). Pemanfaatan Obat Herbal Penurun Panas Pada Balita Sakit Di Desa Kaliurip Kecamatan Purwojati Kabupaten Banyumas. Proceeding Of The Urecol, 644-654.

[54]. Ms, H., \& Wardani, R. A. (2019). Efektivitas Formulasi Teh Herbal Untuk Menurunkan Resiko Gangguan Penyakit Tidak Menular. Jurnal Keperawatan, 12(1), 24-34.

[55]. Ms, H., \& Wardani, R. A. (2019). Efektivitas Formulasi Teh Herbal Untuk Menurunkan Resiko Gangguan Penyakit Tidak Menular. Jurnal Keperawatan, 12(1), 24-34.

[56]. Fanani, Z., Etikasari, R., \& Nugraheni, T. P. (2019). Analisis Makroskopik Dan Mikroskopik Herba Sangketan (Achyranthes Aspera). Proceeding Of The Urecol, 256-262.

[57]. Choironi, N. A., Wulandari, M., \& Susilowati, S. S. (2019). Pengaruh Edukasi Terhadap Pemanfaatan Dan Peningkatan Produktivitas Tanaman Obat Keluarga (Toga) Sebagai Minuman Herbal Instan Di Desa Ketenger Baturraden. Kartika: Jurnal Ilmiah Farmasi, 6(1), 1-5.

[58]. Nurhayati, N., Mulyani, S., \& Efenedy, N. T. (2019). Uji Aktivitas Fraksi Daun Asam Jawa Terhadap Gambaran Histopatologi Pankreas Tikus Putih Jantan.

Farmakologika: Jurnal Farmasi, 16(01), 80-90.

[59]. Komala, L., Hafiar, H., \& Subekti, P. (2016). Jejaring Komunikasi Dalam Penyebaran Informasi Obat Herbal Di Kalangan Pengguna. J-Ika, 3(1), 85-94.

[60]. Harismah, K. (2017). Pemanfaatan Daun Salam (Eugenia Polyantha) Sebagai Obat Herbal Dan Rempah Penyedap Makanan. Warta Lpm, 19(2), 110-118.

[61]. Marpaung, L., Nasution, M. P., Simanjuntak, P., \& Lubis, M. Y. (2018, December). Kulit Biji Jengkol (Archidendron Jiringa (Jack) I. C Nielsen) Sebagai Sumber Obat Herbal Berdasarkan Toksisitas Ekstrak. In Talenta Conference Series: Tropical Medicine (Tm) (Vol. 1, No. 2, Pp. 348-354). 
[62]. Pribadi, E. R. (2015). Pasokan Dan Permintaan Tanaman Obat Indonesia Serta Arah Penelitian Dan Pengembangannya. Perspektif, 8(1), 52-64.

[63]. Djaja, S., Ariawan, I., \& Afifah, T. (2001). Determinan Perilaku Pencarian Pengobatan Infeksi Saluran Pernafasan Atas (Ispa) Pada Balita. Indonesian Bulletin Of Health Research, 29(1).

[64]. Dwiprahasto, I. (2006). Peningkatan Mutu Penggunaan Obat Di Puskesmas Melalui Pelatihan Berjenjang Pada Dokter Dan Perawat. Jurnal Manajemen Pelayanan Kesehatan, 9(02).

[65]. Irawati, A., \& Rozanna, R. (1994). Pemberian Formula Tempe Pada Penderita Gizi Buruk Untuk Mempercepat Penyembuhan. Nutrition And Food Research, 17.

[66]. Adisasmito, W. (2007). Faktor Risiko Diare Pada Bayi Dan Balita Di Indonesia: Systematic Review Penelitian Akademik Bidang Kesehatan Masyarakat. Makara Kesehatan, 11(1), 1-10.

[67]. Palupi, A., Hadi, H., \& Soenarto, S. S. (2009). Satatus Gizi Dan Hubungannya Dengan Kejadian Diare Pada Anak Diare Akut Diruang Rawat Inap Rsup Dr. Sardjito Yogyakarta. Jurnal Gizi Klinik Indonesia, 6(2009).

[68]. Wibowo, T. A. (2003). Faktor-Faktor Risiko Kejadian Diare Berdarah Pada Balita Di Kabupaten Sleman (Doctoral Dissertation, Universitas Gadjah Mada).

[69]. Wulandari, A. P. (2009). Hubungan Antara Faktor Lingkungan Dan Faktor Sosiodemografi Dengan Kejadian Diare Pada Balita Di Desa Blimbing Kecamatan Sambirejo Kabupaten Sragen Tahun 2009 (Doctoral Dissertation, Universitas Muhammadiyah Surakarta).

[70]. Amin, L. Z. (2015). Tatalaksana Diare Akut. Continuing Medical Education, 42(7), 504-508.

[71]. Sumarmin, R. (2018) "Pengaruh Ekstrak Kulit Buah Manggis (Garcinia Mangostana L.) Terhadap Histologis Pankreas Mencit (Mus Musculus L. Swiss Webster) Yang Diinduksi Sukrosa", Eksakta: Berkala Ilmiah Bidang Mipa, 19(1), Pp. 100-112. Doi: 10.24036/Eksakta/Vol19-Iss1/123.

[72]. Sanjaya, H. (2018) "Degradasi Metil Violet Menggunakan Katalis Zno-Tio2 Secara Fotosonolisis", Eksakta: Berkala Ilmiah Bidang Mipa, 19(1), Pp. 91-99. Doi: 10.24036/Eksakta/Vol19-Iss1/131. 
[73]. Chatri, M., Mansyurdin, M., Bakhtiar, A. And Adnadi, P. (2017) "Perbandingan Komponen Minyak Atsiri Antara Daun Muda Dan Daun Dewasa Pada Hyptis Suaveolens (L.)Poit”, Eksakta: Berkala Ilmiah Bidang Mipa, 18(02), Pp. 1-12. Doi: 10.24036/Eksakta/Vol18-Iss02/41.

[74]. Mulia, M. (2017) "Isolasi Kumarin Dari Kulit Buah Limau Sundai (Citrus Nobilis Lour)", Eksakta: Berkala Ilmiah Bidang Mipa, 18(02), Pp. 137-145. Doi: 10.24036/Eksakta/Vol18-Iss02/70.

[75]. Iryani, I., Iswendi, I. And Katrina, I. T. (2017) 'Uji Aktivitas Anti Diabetes Mellitus Senyawa Metabolit Sekunder Fraksi Air Dari Beras Ketan Hitam ( Oryza Satival. Var Glutinosa) Pada Mencit Putih", Eksakta: Berkala Ilmiah Bidang Mipa, 18(01), Pp. 54-60. Doi: 10.24036/Eksakta/Vol18-Iss01/17.

[76]. Rizki Saputra, M. And Sumarmin, R. (2018) "Pengaruh Ekstrak Daun Sirih Merah (Piper Crocatum Ruiz \& Pav.) Terhadap Glukosa Darah Mencit (Mus Musculus L.) Jantan Yang Diinduksi Sukrosa”, Eksakta: Berkala Ilmiah Bidang Mipa, 19(1), Pp. 43-55. Doi: 10.24036/Eksakta/Vol19-Iss1/124.

[77]. Iskandar, I., Horiza, H. And Fauzi, N. (2017) 'Efektivitas Bubuk Biji Pepaya (Carica Papaya Linnaeaus) Sebagai Larvasida Alami Terhadap Kematian Larva Aedes Aegypty Tahun 2015”, Eksakta: Berkala Ilmiah Bidang Mipa, 18(01), Pp. 1218. Doi: 10.24036/Eksakta/Vol18-Iss01/12.

[78]. Putri, D., Fifendy, M. And Putri, M. (2018) "Diversitas Bakteri Endofit Pada Daun Muda Dan Tua Tumbuhan Andaleh (Morus Macroura Miq.)”, Eksakta: Berkala Ilmiah Bidang Mipa, 19(1), Pp. 125-130. Doi: 10.24036/Eksakta/Vol19-Iss1/122.

[79]. Huda, N. (2017) "Pengaruh Ekstrak Sambiloto (Andrographis Paniculata Nees.) Terhadap Siklus Estrus Mencit (Mus Musculus L. Swiss Webster)”, Eksakta: Berkala Ilmiah Bidang Mipa, 18(02), Pp. 69-76. Doi: 10.24036/Eksakta/Vol18-Iss02/55.

[80]. Handayani, D. (2017) "Karakteristik Cendawan Dark Septate Endophyte (Dse) Pada Akar Tanaman Jagung Dan Padi”, Eksakta: Berkala Ilmiah Bidang Mipa, 18(01), Pp. 61-68. Doi: 10.24036/Eksakta/Vol18-Iss01/20.

[81]. Rahmi H.G, I. (2017) “Telaah Faktor-Faktor Yang Mempengaruhi Status Gizi Balita Di Kota Padang Berdasarkan Berat Badan Per Tinggi Badan Menggunakan Metode Cart", Eksakta: Berkala Ilmiah Bidang Mipa, 18(02), Pp. 86-99. Doi: 10.24036/Eksakta/Vol18-Iss02/59. 
[82]. Sari, A. (2017) "Potensi Antioksidan Alami Pada Ekstrak Daun Jamblang (Syzigium Cumini (L.) Skeels)", Eksakta: Berkala Ilmiah Bidang Mipa, 18(02), Pp. 107-112. Doi: 10.24036/Eksakta/Vol18-Iss02/61.

[83]. Setianto, S. (2017) “Analisa Kuantitatif Campuran Senyawa Oksida Sebagai Dasar Identifikasi Kandungan Bahan Sumber Daya Alam Studi Kasus : Kandungan Mineral Pada Pasir Besi Di Pesisir Pantai Selatan, Jawa Barat", Eksakta: Berkala Ilmiah Bidang Mipa, 18(02), Pp. 173-177. Doi: 10.24036/Eksakta/Vol18-Iss02/74.

[84]. Tutuarima, T. (2017) "Sifat Fisik Dan Kimia Marmalade Jeruk Kalamansi (Citrus Microcarpa) : Kajian Konsentrasi Pektin Dan Sukrosa Physical And Chemical Properties Of Marmalade Citrus Of Calamondin (Citrus Microcarpa) : Study Of Pectin And Sucrose Concentrations", Eksakta: Berkala Ilmiah Bidang Mipa, 18(02), Pp. 164-172. Doi: 10.24036/Eksakta/Vol18-Iss02/73.

[85]. Saiya, A. (2017) “Analisis Residu Klorpirifos Dalam Sayuran Kubis Dengan Metode Hplc Di Beberapa Pasar Tradisional Di Sulawesi Utara”, Eksakta: Berkala Ilmiah Bidang Mipa, 18(02), Pp. 77-85. Doi: 10.24036/Eksakta/Vol18-Iss02/57.

[86]. Fati, N., Siregar, R. And Sujatmiko, S. (2019) “Addition Of Coleus Amboinicus, L Leaf's Extract In Ration To Percentage Of Carcass, Abdominal Fat, Liver And Heart Broiler", Eksakta: Berkala Ilmiah Bidang Mipa, 20(1), Pp. 1-9. Doi: 10.24036/Eksakta/Vol20-Iss1/157.

[87]. Putri, D., Anika, M. And Wahyuni, W. (2019) "Bioinformatics Study Genes Encoding Enzymes Involved In The Biosynthesis Of Carotenoids Line Cassava (Manihot Esculenta)", Eksakta: Berkala Ilmiah Bidang Mipa, 20(1), Pp. 10-16. Doi: 10.24036/Eksakta/Vol20-Iss1/161.

[89]. Ramalisa, Y., Febriyanti, A. And Multahadah, C. (2019) “Analysis Of Non Hierarchical Bomb For Collection Of Community Health Degrees In Jambi And Muaro Jambi City”, Eksakta: Berkala Ilmiah Bidang Mipa, 20(1), Pp. 25-34. Doi: 10.24036/Eksakta/Vol20-Iss1/167.

[90]. Suhaemi, Z., Zulkarnaini, Z., Afrijon, A. And Jefri, P. (2019) “The Study Of African Leave (Vernonia Amygdalina) In For Improving The Quality Of Local Duck Meats Of West Sumatera", Eksakta: Berkala Ilmiah Bidang Mipa, 20(1), Pp. 55-59. Doi: 10.24036/Eksakta/Vol20-Iss1/174. 
[91]. Sanjaya, H. (2017) "Degradasi Methylene Blue Menggunakan Katalis Zno-Peg Dengan Metode Fotosonolisis", Eksakta: Berkala Ilmiah Bidang Mipa, 18(02), Pp. 21-29. Doi: 10.24036/Eksakta/Vol18-Iss02/45.

[92]. Dinata, M., Fitridawati, F. And Putri, L. (2019) "The Study Trees Potential For Forest In Universitas Lancang Kuning Pekanbaru", Eksakta: Berkala Ilmiah Bidang Mipa, 20(1), Pp. 77-85. Doi: 10.24036/Eksakta/Vol20-Iss1/176.

[93]. Syafei, N. (2019) "Events Of Corrosion Phenomena On Carbon Steel Pipes In Environment Of Sea Water And Ammonia Solutions Due To The Presence Of Sweet Gas”, Eksakta: Berkala Ilmiah Bidang Mipa, 20(1), Pp. 86-99. Doi: 10.24036/Eksakta/Vol20-Iss1/178.

[94]. Zainul, R. And Wardani, S. (2019) "The Hydrogen Generator Performance Of Sandwich Designed 4/4 Al-Cu Plates", Eksakta: Berkala Ilmiah Bidang Mipa, 20(1), Pp. 100-104. Doi: 10.24036/Eksakta/Vol20-Iss1/177.

[95]. Yanuar, F., Tillah, M. And Devianto, D. (2018) "Modeling Of Human Development Index Using Ridge Regression Method”, Eksakta: Berkala Ilmiah Bidang Mipa, 19(2), Pp. 1-11. Doi: 10.24036/Eksakta/Vol19-Iss2/134.

[96]. Enjelina, W., Mansyurdin, M. And Meideliza, T. (2018) “Analysis Of Nepenthes Hybrids In Bukik Taratak West Sumatra By Rapd Technique”, Eksakta: Berkala Ilmiah Bidang Mipa, 19(2), Pp. 12-20. Doi: 10.24036/Eksakta/Vol19Iss2/137.

[97]. Santoso, B., Setianto, S., Hasanah, M., Wijatmoko, B., Supriyana, E. And Mohammad, H. (2018) "Mitigation Of Land Movement Using Self Potential Method In Ling-Anjung Region Sumedang Regency", Eksakta: Berkala Ilmiah Bidang Mipa, 19(2), Pp. 32-39. Doi: 10.24036/Eksakta/Vol19-Iss2/141.

[98]. Parbuntari, H., Prestica, Y., Gunawan, R., Nurman, M. And Adella, F. (2018) "Preliminary Phytochemical Screening (Qualitative Analysis) Of Cacao Leaves (Theobroma Cacao L.)", Eksakta: Berkala Ilmiah Bidang Mipa, 19(2), Pp. 40-45. Doi: 10.24036/Eksakta/Vol19-Iss2/142.

[99]. Dinata, M. And Soehardi, F. (2018) "Factor Analysis Of Physics Chemistry Waters That Affects Damage Safety Cliff On The Outskirts Of River Siak", Eksakta: Berkala Ilmiah Bidang Mipa, 19(2), Pp. 46-49. Doi: 10.24036/Eksakta/Vol19Iss $2 / 143$. 
[100]. Harahap, F. And Lubis, L. (2018) “Analysis Of Heavy Metals Distribution In The River Town Of Hamasaki’s Rod Padangsidimpuan”, Eksakta: Berkala Ilmiah Bidang Mipa, 19(2), Pp. 50-56. Doi: 10.24036/Eksakta/Vol19-Iss2/149.

[101]. Badrulfalah, B., Irianingsih, I. And Joebaedi, K. (2018) "Some Operations On Mixed Monotone Operator In Banach Spaces", Eksakta: Berkala Ilmiah Bidang Mipa, 19(2), Pp. 57-61. Doi: 10.24036/Eksakta/Vol19-Iss2/150.

[102]. Joebaedi, K., Parmikanti, K. And Badrulfalah, B. (2018) "First Order Space Time Autoregressive Stationary Model On Petroleum Data”, Eksakta: Berkala Ilmiah Bidang Mipa, 19(2), Pp. 62-69. Doi: 10.24036/Eksakta/Vol19-Iss2/152.

[103]. Vauzia, V. And Gusmira, E. (2018) "The Response Of Jabon Seeds Germination (Anthocephalus Cadamba (Roxb.)Miq.) Against The Duration Of Combustion And Illumination", Eksakta: Berkala Ilmiah Bidang Mipa, 19(2), Pp. 8087. Doi: 10.24036/Eksakta/Vol19-Iss2/154.

[104]. Horiza, H. (2018) "The Influence Of The Use Of Activated Carbon Fibres Of The Cane Against The Drop In Salinity In The Well Dig In Rt 003 Rw 006 Village Cape Town Unggat Tanjungpinang Year 2017', Eksakta: Berkala Ilmiah Bidang Mipa, 19(1), Pp. 1-6. Doi: 10.24036/Eksakta/Vol19-Iss1/97.

[105]. Syafei, N. (2018) "Riset Material Analisa Fenomena Korosi Pelat Pipa Baja Karbon Api 51-X65 Dalam Larutan 7900 Ml Air Laut Dan 100 Ml Amoniak Pada Kondisi Gas Co2 Dan H2s Jenuh Pada Suhu Ruang.", Eksakta: Berkala Ilmiah Bidang Mipa, 19(1), Pp. 7-13. Doi: 10.24036/Eksakta/Vol19-Iss1/83.

[106]. Ruswandi, R. (2018) "Determination Of Fructose Content Resulted By Inulin Hydrolysis With Dns As Oxidizer”, Eksakta: Berkala Ilmiah Bidang Mipa, 19(1), Pp. 14-23. Doi: 10.24036/Eksakta/Vol19-Iss1/102.

[107]. Joebaedi, K. (2018) "Model Star(1;1) Pada Data Produktivitas Teh", Eksakta: Berkala Ilmiah Bidang Mipa, 19(1), Pp. 35-38. Doi: 10.24036/Eksakta/Vol19Iss1/118.

[108]. Hidayani, T. (2018) "Grafting Polipropilena Dengan Maleat Anhidrida Sebagai Pengikat Silang Dengan Inisiator Benzoil Peroksida”, Eksakta: Berkala Ilmiah Bidang Mipa, 19(1), Pp. 56-62. Doi: 10.24036/Eksakta/Vol19-Iss1/127.

[109]. Advinda, L. (2018) "Pertumbuhan Stek Horizontal Batang Jarak Pagar (Jatropha Curcas L.) Yang Diintroduksi Dengan Pseudomonad Fluoresen”, Eksakta: 
Berkala Ilmiah Bidang Mipa, 19(1), Pp. 68-75. Doi: 10.24036/Eksakta/Vol19Iss 1/129.

[110]. Samah, S. (2017) "Karakterisasi Plastik Biodegradabel Dari Ldpe-G-Ma Dan Pati Tandan Kosong Sawit", Eksakta: Berkala Ilmiah Bidang Mipa, 18(02), Pp. 3038. Doi: 10.24036/Eksakta/Vol18-Iss02/48.

[111]. Zainul, R. (2019, January 15). F. Https://Doi.Org/10.31227/Osf.Io/75pdj

[112]. Nurfadilah, K. K., \& Zainul, R. (2019, February 3). Kalium Nitrat (Kno3):

Karakteristik Senyawa Dan Transpor Ion. Https://Doi.Org/10.31227/Osf.Io/Dr8ef

[113]. Febriani, S. S., Yolanda, T., Arianti, V. A., \& Zainul, R. (2018, October 12). A Review Solid Stated : Principles And Methode.

Https://Doi.Org/10.31227/Osf.Io/7us4x

[114]. Zainul, R. (2018, August 16). Design And Modification Of Copper Oxide Electrodes For Improving Conversion Coefficient Indoors Lights (Pv-Cell) Photocells. Https://Doi.Org/10.31227/Osf.Io/Pgn84

[115]. Zainul, R. (2018, August 16). Determination Of The Half-Life And The Quantum Yield Of Zno Semiconductor Photocatalyst In Humic Acid. Https://Doi.Org/10.31227/Osf.Io/E8a9x

[116]. Kristy, D. P., \& Zainul, R. (2019, February 3). Analisis Molekular Dan Transpor Ion Natrium Silikat. Https://Doi.Org/10.31227/Osf.Io/8ac4m

[117]. Artika, P. I., \& Zainul, R. (2018, November 19). Potassium Bromide (Kbr): Transformasi Ionik Dan Sifat Temodinamika Dalam Larutan.

Https://Doi.Org/10.31227/Osf.Io/A5hyz

[118]. Zainul, R., \& Prima, C. B. (2018, November 11). Desain Geometri Sel Pv. Https://Doi.Org/10.31227/Osf.Io/7n8t4

[119]. Lubis, A. P., \& Zainul, R. (2018, November 5). Interaksi Molekuler Amonium Hidroksida. Https://Doi.Org/10.31227/Osf.Io/Jht3b

[120]. Husna, H., \& Zainul, R. (2019, February 3). A Review : Aspek Termodinamika Lino3 Dalam Larutannya. Https://Doi.Org/10.31227/Osf.Io/45mbd 
[121]. Zainul, R., \& Prima, C. B. (2018, December 9). TEKNOLOGI MATERIAL MAJU

Prinsip Dasar dan Aspek Rekayasa. https://doi.org/10.31227/osf.io/p63wc

[122]. Zainul, R. (2018, August 16). Design And Modification Of Copper Oxide Electrodes For Improving Conversion Coefficient Indoors Lights (Pv-Cell) Photocells. Https://Doi.Org/10.31227/Osf.Io/Pgn84

[123]. Zainul, R. (2018, August 16). Determination Of The Half-Life And The Quantum Yield Of Zno Semiconductor Photocatalyst In Humic Acid. Https://Doi.Org/10.31227/Osf.Io/E8a9x

[124]. Zainul, R. (2018, August 16). Effect Of Temperature And Particle Motion Against The Ability Of Zno Semiconductor Photocatalyst In Humic Acid. Https://Doi.Org/10.31227/Osf.Io/Wnygb

[125]. Liza, Y. M., Yasin, R. C., Maidani, S. S., \& Zainul, R. (2018, October 9). Sol Gel : Principle And Technique (A Review). Https://Doi.Org/10.31227/Osf.Io/2cuh8

[126]. Dinata, A. A., Rosyadi, A. M., Hamid, S., \& Zainul, R. (2018, October 15). A Review Chemical Vapor Deposition : Process And Application.

Https://Doi.Org/10.31227/Osf.Io/Yfeau

[127]. Putri, D. F., Ritonga, H. M., Murdiati, V., \& Zainul, R. (2018, October 15). A Review What Is Hydrothermal ?. Https://Doi.Org/10.31227/Osf.Io/Dm56c

[128]. Zainul, R., \& Prima, C. B. (2018, November 11). Desain Geometri Sel Pv. Https://Doi.Org/10.31227/Osf.Io/7n8t4

[129]. Dinata, A. A., Rosyadi, A. M., Hamid, S., \& Zainul, R. (2018, October 15). A Review Chemical Vapor Deposition : Process And Application. Https://Doi.Org/10.31227/Osf.Io/Yfeau

[130]. Warlinda, Y. A., \& Zainul, R. (2019, January 29). Asam Posfat (H3po4): Ionic Transformation Of Phosphoric Acid In Aqueous Solution. Https://Doi.Org/10.31227/Osf.Io/S3y8v

[131]. Alfionita, T., \& Zainul, R. (2019, January 29). Calcium Chloride (Cacl2) : Characteristics And Molecular Interaction In Solution. Https://Doi.Org/10.31227/Osf.Io/M37xj

[132]. Chaidir, Z., Zainul, R., Nurakhbari, D., \& Salim, M. (2018, July 29). Optimization Of Spirulina Platensis Culture For Antioxidant Production. Https://Doi.Org/10.17605/Osf.Io/Fd6e4 
[133]. Yuliani, F., \& Zainul, R. (2018, November 13). Analisis Termodinamika Molekul Magnesium Sulphate (Mgso4). Https://Doi.Org/10.31227/Osf.Io/Uxz4y

[134]. Sari, M., \& Zainul, R. (2018, November 19). Kalium Dikromat (K2cr2o7) Spektroskopi Dan Transpor K2cr2o7. Https://Doi.Org/10.31227/Osf.Io/W92je

[135]. Yulis, R., Zainul, R., \& M. (2018, December 10). Desain Dan Karakterisasi

Sel Surya Sistem Elektroda Tembaga (I) Oksida (Cu2o/Al) Model Pipa Pada Larutan Natrium Sulfat (Na2so4). Https://Doi.Org/10.31227/Osf.Io/M43js

[136]. Artika, P. I., \& Zainul, R. (2018, November 19). Potassium Bromide (Kbr): Transformasi Ionik Dan Sifat Temodinamika Dalam Larutan. Https://Doi.Org/10.31227/Osf.Io/A5hyz

[137]. Yanti, C. F., \& Zainul, R. (2018, December 2). A Review Ba (Oh)2 : Transpor Ionik Pada Barium Hidroksida Di Dalam Air Dengan Konsep Termodinamika. Https://Doi.Org/10.31227/Osf.Io/Fsbq3

[138]. M., Sanjaya, H., \& Zainul, R. (2018, August 11). Characterization Of Napa Soil And Adsorption Of $\mathrm{Pb}$ (Ii) From Aqueous Solutions Using On Column Method. Https://Doi.Org/10.31227/Osf.Io/T8fh9

[139]. Shafitri, M., \& Zainul, R. (2019, February 3). Vanadium Pentaoksida (V2o5) : Termodinamika Molecular Dan Interaksi Ion Dalam Larutan. Https://Doi.Org/10.31227/Osf.Io/Jgmvd [140]. P, O. M., A, L. G., S, A. Y. M., \& Zainul, R. (2018, October 12). A Review Grinding : Teknik Dan Prinsip Dasar Pada Pengolahan Material. Https://Doi.Org/10.31227/Osf.Io/Trv4q

[141]. Hakimi, A., \& Zainul, R. (2019, January 31). Asam Arsenat (H3aso4) : Analisis Molekular Dan Karakteristik Senyawa. Https://Doi.Org/10.31227/Osf.Io/E486z

[142]. Delvi, I. P., \& Zainul, R. (2019, February 3). Mercury (Ii) Nitrate (Hg (No3)2): Interaksi Molekul Dan Adsorpsi Hg Dengan Karbon Aktif. Https://Doi.Org/10.31227/Osf.Io/Eqyax

[143]. Dwynda, I., \& Zainul, R. (2018, November 19). Boric Acid (H3 (Bo3): Recognize The Molecular Interactions In Solutions. Https://Doi.Org/10.31227/Osf.Io/6wead 
[144]. Rahmadhanty, S., \& Zainul, R. (2018, December 24). Design Of Humat Acid Solid Solution Reactor Through Phototransformation Of Copper Oxide (Cuo) Semiconductor Plate. Https://Doi.Org/10.31227/Osf.Io/Yhd9x

[145]. Zainul, R., Alif, A., Aziz, H., Arief, S., \& S. (2018, August 16).

Photoelectrosplitting Water Mechanism At Carbon Electrode Surface Using Indoor Lights. Https://Doi.Org/10.31227/Osf.Io/Vcxq8

[146]. H., Azhar, M., \& Zainul, R. (2018, September 19). The Effectiveness Of Structured Inquiry Based Module To Improve Mental Model Of Concept Mole. Https://Doi.Org/10.31227/Osf.Io/Ckjtb

[147]. Y., \& Zainul, R. (2018, November 18). Silver Sulfate (Ag2so4): Molecular Analysis And Ion Transport. Https://Doi.Org/10.31227/Osf.Io/N8g9k

[148]. Zainul, R. (2018, August 16). Effect Of Temperature And Particle Motion Against The Ability Of Zno Semiconductor Photocatalyst In Humic Acid. Https://Doi.Org/10.31227/Osf.Io/Wnyg

[149]. Feronika, N. I., \& Zainul, R. (2018, November 19). Kalium Permanganat: Termodinamika Mengenai Transport Ionik Dalam Air. Https://Doi.Org/10.31227/Osf.Io/G6eyk [150]. Jumalia, R., \& Zainul, R. (2019, February 3). Natrium Karbonat : Termodinamika Dan Transport Ion. Https://Doi.Org/10.31227/Osf.Io/Y2vq9 